\title{
Spirit of Balinese Local Heroes Transformed into Puppets Show on YouTube as ELT Media for Building Students' Character
}

\author{
I Putu Yoga Purandina ${ }^{1 *}$, Kadek Adyatna Wedananta ${ }^{2}$ iD \\ ${ }^{I}$ Sekolah Tinggi Agama Hindu Negeri Mpu Kuturan, Singaraja, Indonesia \\ ${ }^{2}$ Universitas Pendidikan Nasional, Denpasar, Indonesia \\ *Corresponding author: yogapurandina@stahnmpukuturan.ac.id
}

\begin{abstract}
Balinese Local Heroes should be role models for all children around Bali. The spirit of the heroes is full of positive characters. Those characters are essential in building a good personality in every single kid. This study aims to analyze Balinese local heroes' effect into puppets show on Youtube as ELT media for building students' character. The research was designed as a qualitative study. The data taken from the observed interaction at the puppets showed on YouTube that students watched. The obtained data were students' and parent's data interviews and questionnaires. The study results showed that Balinese Local Heroes' spirit transformed into puppet shows on YouTube affected students accurately because the media was engaging. Some character values were affected, willingness to sacrifice, bravery, defense of truth and justice, noble, responsible, and patriotic. The social function of all of the values was essential. The values transformed into a positive attitude in social life. The student became a good helper to the people who need help. They clean the environment without any intention and have a responsibility to do their duty as a student.
\end{abstract}

Keywords: Balinese Local Heroes, ELT Media, Character

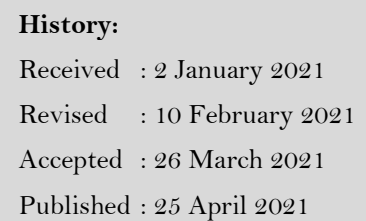

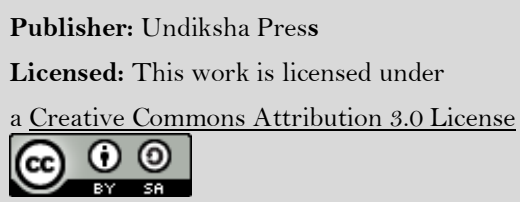

Publisher: Undiksha Press

a Creative Commons Attribution 3.0 License

\section{Introduction}

English Language Teaching (ELT) has undergone fundamental changes. Learning English today cannot be separate from the influence of technology, especially the internet (Anand et al., 2020). These changes affect fundamental changes to the methods, strategies, techniques, media, and resources of learning English. Learning resources are used mainly through the internet, so that the media used is mostly text, audio-visual, and teaching aids that are accessed via the internet (Pandya, 2016). The internet provides various engaging learning media to be more enthusiastic, especially more enthusiastic in English learning. One of them can be accessed via YouTube. YouTube is a website that shares videos containing various engaging content as a medium for learning English. Teachers are starting to switch from using conventional techniques, strategies, or methods to digital or online teaching methods, one of which is via YouTube (Anugerah et al., 2019; Nasution, 2019). By using the YouTube site, students only need to access videos shared via YouTube by the teacher. Then students can be trained in the four primary skills in learning English, such as listening, reading, and speaking, and writing, so that the use of YouTube as a learning medium is perfect for English learning (Hakim, 2019).

Learning English through YouTube is very good because there are various English learning content on this site, especially learning English for children (Saiful, 2019). Audio- 
visual-based learning media have recently become more attractive to children. Audio-visualbased learning media, in the form of video, besides being more attractive, will also stimulate the child's five senses to develop more (Maulina, 2017; Rakiyah, 2014; Winarto et al., 2020). The sense of sight, most of the hearing, is directly affected by the content contained in the YouTube video. So for English language learning, video media via YouTube is very good and effective. Besides, children are excellent imitators (Rustan, 2020; Suhana, 2018). So it will be effortless to introduce and teach children a second language, especially this foreign language or English. Learning English is developing four primary skills, namely listening, reading, speaking, and writing. Listening and reading are abilities that individuals must possess to receive or obtain information. Conversely, speaking and writing are the ability to provide or transfer information. So it is perfect if these four skills can be developed by learning through YouTube.

Furthermore, English skills can be developed through YouTube media, but it can also be accompanied by immersion in character education through story content or storytelling on YouTube media (Dwiaryanti, 2018). Through good characterizations or characters who can become idols among children. As mentioned earlier, children are excellent imitators, so it is effortless for them to imitate exemplary attitudes through folklore, fairy tales, and fables (Nurapriani et al., 2019). This media is often referred to as digital storytelling. Children accompanied by their parents will find it very easy to access these rich stories with exemplary values that children can imitate (Golann, 2017). These two domains can be developed well through YouTube, where children are invited to watch English-language stories on YouTube full of character values (Halimah et al., 2020). It would be even more interesting if this digital storytelling were packaged in the form of a puppet show. Puppet show (Wayang performances) are one of the indigenous cultures of the Indonesian people. In contemporary times, this puppet show may be considered ancient. Sometimes children are less interested in Wayang performances in real life, which are still very traditional. Nevertheless, even so, the puppet show is, in fact, a show. Of course, the purpose of a show is to entertain so that the audience will be interested. It would be bizarre if the puppet shows did not appeal to children. Thus, there must be a little adapted to today's children.

Previous research conducted by Hermayawati (2019) used the blended learning method, which uses the internet media, especially YouTube, to assess Wayang Orang groups used as English learning media, especially in the writing aspect applying self-assessment in it. The goal is to improve the ability of self-writing aspects by knowing the weaknesses of students themselves. In addition, this is an effort to utilize and cultivate the preservation of local wisdom, namely wayang orang in the Yogyakarta area. In line with this, research conducted by Cahyono (2017) explained that illustrated animated stories displayed on YouTube, such as wayang are indeed fascinating and full of character values. Likewise, the community service carried out by Fajri \& Hestaliana (2019) implemented puppets for kindergarten teachers. Because in the puppet show, which is in the form of hero narratives full of moral values. This shows that the learning media that uses wayang is very suitable in cultivating character and introducing English.

Paying attention to previous research, researchers are interested in researching Students of Early Childhood Education Teacher Education, Sekolah Tinggi Agama Hindu Negeri Mpu Kuturan Singaraja, who are very interested in developing English learning while simultaneously instilling these character values through wayang performances on YouTube media. Students who carry out Perspective Teacher Program or Program Pengalaman Lapangan (PPL) choose YouTube as a medium for learning English for children. Children are expected to speak English and have character according to noble attitudes and behavior to their respective regions. This regional attitude is essential to maintain the children's identity as their identity in diversity (Dewi et al., 2019). Therefore, this PPL student chose stories of 
local Balinese heroism as stories or plays for wayang performances that were displayed on YouTube media. The local Balinese heroes referred to here are the heroes of the struggle of the Balinese people, both during the kingdom era such as Kebo Iwa, I Gusti Ketut Jelantik, Ki Panji Sakti, Sagung Wah, Nyoman Gempol, and Dewa Agung Jambe. Likewise, Balinese heroes who fought during the independence period, such as I Gusti Ngurah Rai, I Gusti Ketut Pudja, and I Gusti Putu Wisnu. The obstacles faced are, of course, stories about these characters that are very difficult to find. Therefore, the stories obtained are limited to word of mouth, which requires improvisation by the storyteller. This is the biggest challenge for PPL students of the State College of Hindu Religion Mpu Kuturan Singaraja in carrying out English language learning using the wayang performance method via YouTube media.

However, whether the learning of English, which is designed and carried out by PPL students, successfully influences children to be more enthusiastic and motivated and can instill the values of character education that influence and influence the social functions. This is what is explored further in this research. In this study, the researcher wanted to know the extent to which the effectiveness of English learning with the digital storytelling model in this wayang performance was able to be effective and motivate children to learn English and imitate the attitudes of local Balinese heroes. The study used English Language Learning Media through narrative texts or stories or storytelling to children. Furthermore, theories on English learning regarding Story Telling are used combined with learning theories using YouTube video content. In addition, to find out more about Character Building, use the Local Wisdom and Character Education theory, especially Balinese Culture.

This study aims to analyze Balinese local heroes' effect into puppets show on Youtube as ELTmedia for building students' character. The writer uses the theory of English learning media through narrative text using YouTube media. It is coupled with the theory of motivation that affects learning English for children.

\section{Materials and Methods}

The research design used in this study is qualitative research. Qualitative research focuses on investigating the quality of relationships, activities, sites, and materials (Fraenkel \& Wallen, 2008). This research is a qualitative descriptive study in which the setting, place, condition, and situation are direct data, and the researcher has a central role as a key to all existing instruments (Key Instrument) (Gerring, 2007). Furthermore, this qualitative descriptive research is very suitable for investigating certain people, events, groups of people, and institutions.

In this study, the authors analyzed the influence of Balinese Local Heroes Transformed into Puppet Show on YouTube as ELT Media Building Students' Character by PAUD Perspective Teacher in STAHN Mpu Kuturan Singaraja. The data used are the results of interviews with children, parents, and PPL students. In addition, a questionnaire was also distributed via Google form to find out the children's attitudes, whether learning using digital storytelling was effective in motivating students or not. This questionnaire also aims to determine the value of character education that can influence and what social functions affect changes in children's attitudes (Asadullina et al., 2020).

Researchers analyzed data obtained from interviews (interview guide) and questionnaires distributed through the WhatsApp group of parents of children/students. This questionnaire was created using the Google Form application, which was created and validated by experts. All instruments used in this research are appropriate and appropriate instruments for conducting qualitative descriptive research methods. Indeed, to achieve research objectives like this must be assisted by instruments in observing and obtaining data (Heigham \& Croker, 2009; Hung et al., 2018). To get the right and appropriate data, reliable and valid data must be obtained. The data obtained must be cross-checked and repeated to 
find valid data that is often referred to as Data Triangulation (Flick, 2018; Moleong, 2013; Noble \& Heale, 2019). Campbell and Fiske add that triangulation is an approach or way to obtain accurate data using different data collection strategies or combinations (Roulston, 2018). In addition, trustworthiness data is also carried out in this study, focusing on four aspects: data, data transcription, data collection techniques, and findings.

Data analysis was carried out based on the Miles-Huberman approach, which consists of three concepts, namely data reduction, which has been carried out directly at the time of data collection, second is the presentation of data (Data Display), and verification of conclusion drawings (Miles \& Huberman, 1994; Renz et al., 2019; Sugiyono, 2019). This analytical approach is an activity that is directly involved in the investigation process. Once the data is obtained, it will be directly analyzed as a form of the investigation process. Analyzing the data is carried out interactively and simultaneously until all problems in this research are answered, or a solution is obtained. Data reduction is made very carefully where only the necessary data is taken according to the problem research. The data in question follows the spirit of Balinese Local Heroes Transformed into Puppet Show on YouTube as ELT Media Building Students' Character by PAUD Perspective Teacher in STAHN Mpu Kuturan Singaraja in the data will be discarded or, in other words, discarded.

\section{Results and Discussion Findings}

This research lasted for three months, and during those three months, it was found that the learning of English for PAUD by STAHN Mpu Kuturan students ran smoothly. Thus, three results and discussions were carried out at this stage by the research problem that was determined previously.

\section{Student and Parents' Feedback}

Learning using YouTube media in the form of puppet shows is very influential on children. The effect in question is that children are more enthusiastic about participating in learning English via YouTube. This learning can motivate children to take this English class. The following is a questionnaire filled out by children and parents regarding the influence of the spirit of Balinese Local Heroes is affected or not to PAUD students.

Table 1. Student and Parents' Feedback

\begin{tabular}{|c|c|c|c|c|c|}
\hline \multirow{3}{*}{ Description } & \multicolumn{5}{|c|}{ Score } \\
\hline & \multicolumn{2}{|c|}{ Disagree } & \multirow{2}{*}{$\stackrel{\leftrightarrow}{2}$} & \multicolumn{2}{|c|}{ Strongly agree } \\
\hline & 0 & 1 & & 3 & 4 \\
\hline This puppets show are interesting & $0 \%$ & $0 \%$ & $3 \%$ & $83 \%$ & $14 \%$ \\
\hline Children are passionate about learning & $0 \%$ & $0 \%$ & $1 \%$ & $91 \%$ & $8 \%$ \\
\hline $\begin{array}{l}\text { Children are able to recognize several } \\
\text { vocabulary in English }\end{array}$ & $0 \%$ & $1 \%$ & $6 \%$ & $82 \%$ & $11 \%$ \\
\hline Children like the puppets show & $0 \%$ & $0 \%$ & $1 \%$ & $36 \%$ & $63 \%$ \\
\hline $\begin{array}{l}\text { Children are able to understand stories in } \\
\text { puppets performance }\end{array}$ & $0 \%$ & $1 \%$ & $4 \%$ & $73 \%$ & $22 \%$ \\
\hline $\begin{array}{l}\text { Children are able to understand the moral } \\
\text { values of story }\end{array}$ & $0 \%$ & $2 \%$ & $8 \%$ & $77 \%$ & $13 \%$ \\
\hline $\begin{array}{l}\text { Children need parental guidance in this } \\
\text { learning }\end{array}$ & $0 \%$ & $0 \%$ & $0 \%$ & $16 \%$ & $84 \%$ \\
\hline
\end{tabular}


Table 1 above is a table based on feedback from students and parents regarding learning English through puppet performances about heroic stories through YouTube media. The data in table 1 is obtained by distributing questionnaires to children and parents after watching a puppet performance on YouTube media. In the table, it is known that this puppet show can attract the attention of students. This is indicated by the statements of students and parents who mostly agree that the puppet show is interesting. Furthermore, after confirmation from the interview data, it was found that the parents' statements stated that their children liked this show and were always enthusiastic about watching the shows on this YouTube media.

\section{Character Values Found in the Puppets Show on YouTube}

The second result is about character values grown through learning English through the storytelling method of this Wayang performance on YouTube. The results obtained are that six fundamental character values can be grown through puppet performances on YouTube. The six values are Willing to sacrifice, bravery, in defense of truth and justice, noble, responsible, and patriotic. These six values were obtained after going through collecting data through the interview method and distributing questionnaires via Google Form to PPL teachers and parents of students.

Before distributing the questionnaire, the authors conducted interviews with PPL teachers and parents about what character values can be cultivated in children through staging puppets on YouTube. Interview data shows that the values that can be collided are reduced to six values, such as Willing to sacrifice, bravery, in defense of truth and justice, noble, responsible, and patriotic. Then carried out questionnaires regarding the six values of character education to strengthen the data in answering this second research question. The following is a table regarding the character values grown through puppet performances about the local Balinese heroic spirit on YouTube.

Table 2. Character Values that Built from the Show (Perspective Teachers and Parents' Perception)

\begin{tabular}{lcc}
\hline \multirow{2}{*}{ Description } & \multicolumn{2}{c}{ Score } \\
\cline { 2 - 3 } & Perspective Teachers & Parents \\
\hline Willing to sacrifice & $98 \%$ & $94 \%$ \\
Bravery & $96 \%$ & $90 \%$ \\
In defence of truth and justice & $96 \%$ & $90 \%$ \\
Noble & $94 \%$ & $92 \%$ \\
Responsible & $94 \%$ & $94 \%$ \\
Patriotic & $100 \%$ & $98 \%$ \\
Others Positive Values & $60 \%$ & $68 \%$ \\
\hline
\end{tabular}

The data in Table 2 above clearly shows the perceptions of PPL teachers and parents about the six values of character education that can be grown in children through puppet performances about the local Balinese heroism on YouTube. In these data, the patriotic score received a relatively large response, namely $100 \%$ from teachers and $98 \%$ from parents of students.

\section{Social Function of the Character Values found on Puppets Show on YouTube}

The social functions that arise from the values of character education that are grown are very influential in children's daily lives. The six values of character education above greatly influence children's attitudes and behavior. Indeed, it is no longer relevant to use weapons to repel invaders, but children must imitate the exemplary attitudes of heroism in the 
puppet performance stories on the YouTube site as positive attitudes and behaviors. The value of this noble character education will be imitated by children under the environment and the challenges they will face later (Sulistiyanto et al., 2019; Swart et al., 2019).

\section{Discussion \\ Spirit of Balinese Heroes Transformed into Puppet Show on YouTube affected the PAUD Students.}

The Data shows that children are excited about this puppet show. Most of the students' parents stated that their children were always excited to watch this puppet show. The children are also able to recognize some simple English vocabulary and sentences used in this puppet show. This puppet show uses two languages, namely English and Indonesian, sometimes even using local languages when PPL teachers want to insert local terms in the show. The story in this puppet show is fascinating. Most students and parents agree that their children like these stories of local Balinese heroism. They were initially unfamiliar with the heroic characters in the puppet show stories, but they became very familiar with these characters after watching and receiving direct guidance from parents and PPL teachers.

Interviews with the students 'parents showed that their children had a little difficulty understanding the storyline, but with the parents' guidance, this simple short story about the spirit of the local Balinese heroes could be understood and enjoyed every story they saw. The packaged stories are not too complex but are very simple so that children can still understand them. However, children still cannot understand complex stories. Indeed, the children still have to get much guidance from parents so that they can better understand the stories in this puppet show. Likewise, the moral message conveyed through the narrative story of the puppet show is quite difficult for children to understand. The message must be explained again by the PPL teacher and also explained by their parents. Apart from PPL teachers, parents also have an essential role in this learning. Parents cannot let their children take part in learning by watching performances of local Balinese heroic stories. Instead, they must always be accompanied by their parents.

Learning media is indeed a tool used by teachers to convey messages and information on the subject matter in the teaching and learning process so that learning is more exciting and stimulates student attention (Donohue, 2014; Mabruri et al., 2019). All the media have plus-minus in their function, but learning through audio-visual media tends to be more interesting than learning using other media (Parette \& Blum, 2013; Purandina, 2020). Learning through audio-visual media can stimulate the senses of hearing and sight in absorbing messages contained in the media. Furthermore, using YouTube as a medium for learning English is exact and effective in conveying a message that the teacher wants to convey. YouTube is one of the most popular video-sharing websites on the internet today. Everyone children access this YouTube site every day. Therefore, it shows that YouTube media is very close to the daily life of students. YouTube is classified as audio-visual media that contains sound and images that can be seen and moved. So that learning via YouTube is undoubtedly very interesting for children (Yusuf, 2020). So that by using YouTube, children will tend to help display objects that are limited in space and time, such as very large or very small objects or a natural event that takes a long time, making it difficult for students to gain direct experience regarding this matter. In addition, learning English through storytelling methods for children is also very effective in developing children's English skills. The storytelling approach to learning is one of several suitable approaches for early childhood development (Morat et al., 2017). Apart from stories, it can also be done by using roleplaying methods, arts and crafts, games, show and tell, and movements and songs. Learning that is carried out by telling the storytelling method about the local Balinese heroic spirit on YouTube includes a mixed approach, which combines the storytelling approach, role-playing, 
show and tells, and movement and song. Furthermore, learning English with this storytelling method can introduce new vocabulary to children. The vocabulary is often repeated during the puppet show process so that children can understand different vocabulary with the context of events that occur in events in the story (Leong et al., 2019). So it can be said that overall, English learning through storytelling methods by uplifting the local Balinese heroic spirit through YouTube is effective for children.

\section{Character Values Affected in Building PAUD Students' Characters}

This patriotic value is quite a lot found in this local Balinese heroic story. For example, when the hero is fighting against the invaders to defend his homeland. Patriotic is a character's attitude towards love for the homeland, so that it means to defend the homeland to death. The values of this patriotic character include other character attitudes such as discipline, willingness to sacrifice, and obedience to applicable rules. The second value is willing to sacrifice. The character value is an attitude of a character who strives for the interests of many people above their interests. Even someone with this attitude dared to sacrifice his life for the sake of his people and nation. This character value can be seen in every struggle made by heroic characters in the stories that are staged in the puppet show on the YouTube site. This character value is a positive character value that is very good for growing in children.

The third character value is bravery: the karate value on which every other character is based. Every individual needs this character attitude to encourage himself to take positive action. An individual with this courageous attitude must have a good soul and great selfconfidence. However, it is still under the positive realm, not brave in the negative sense. Someone who has this attitude is good at facing every challenge, even the most difficult. In this heroic story, of course, this attitude is reflected in every local Balinese hero in his courage to make decisions and fight against the invaders. The fourth character value is in defense of truth and justice. Someone who has this character value will have an attitude that always defends the rights of the oppressed. In this case, the rights of the indigenous people who were colonized. These heroes tried to fight for the indigenous people who were oppressed and seized by the colonialists. This is certainly not fair for the indigenous people who own this homeland. Moreover, the colonizers arbitrarily treated the people like slaves. Therefore, these figures are championed by these figures. This value is very well instilled in children to have an attitude that always defends truth and justice.

The fifth character value is noble. This character value is undoubtedly the result of positive behavior that someone has done. A person can be said to be noble if someone has taken positive actions and has had a good impact on society. For example, helping the community from distress, and helping the community from injustice. A hero is certainly very noble because he has a patriotic spirit, nationalism, and high humanity and always sacrifices the wider community. The sixth character value is responsible. The disturbance is a character value reflected in the attitude of one's self-awareness of behavior that is done either intentionally or unintentionally. Responsibility comes from being willing from the bottom of the heart. This is reflected in the heroism attitude, the responsibility to defend his homeland and save his people from arbitrariness. The heroes in this puppet show are also mostly leaders who have the responsibility to defend their people. Other character values are obtained through interviews, but these have been reduced to these six main character values (Umaya et al., 2016; Wijayanti \& Sulaksono, 2019).

\section{Social Function of the Caracter Values affected in Children's Social Life}

For example, the value of willing to sacrifice character education will be very beneficial for children if the children can emulate this value. If children have behavioral 
attitudes that reflect the value of willing to sacrifice, they will always be accustomed to fighting for the interests of many people or the public's interests above their interests. In a social environment where children grow up, they will be accustomed to socializing with family, friends, teachers, and the community by showing mutual assistance, always willing to sacrifice themselves or their belongings for the more important benefit of many people (Purandina \& Winaya, 2020). In childhood, children can be guided to help each other, help unconditionally, and give or share what they have to help others who need help (Dahyat et al., 2020).

The value of bravery character education is suitable for children in terms of courage to face all challenges. Do not let children become a generation of weak cowards, easily influenced and weakened by those who want to take away the honor of themselves, their families, or the nation. A demanding generation who is always alert to every challenge and situation. Able to find a way out of every difficulty and always be responsive and comfortable with solving a problem. Children must be accustomed to engaging in challenging activities such as participating in competitions or competitions during this childhooddrawing, storytelling, coloring, and singing competitions (Tetep \& Suparman, 2019). Mental children must always be trained, such as speaking in public and communicating with other people. The value of character education in defense of truth and justice is also outstanding in developing children's attitudes and behavior. Children will learn to recognize what is good and what is bad for many people. In addition, children can sort out what is called fair and what is justice for many people. This can be started from simple things related to obeying the rules and norms that apply in the family, school, and society. Children are also accustomed to respecting the rights of others and their obligations.

The value of noble has a social function as forming a noble soul, love for others. This value is also related to other positive character education values: being willing to sacrifice, helping each other, and being patriotic. At the age of this mistaken child can be grown by loving every living thing by protecting the environment, helping each other, and loving fellow human beings by making friends with anyone without discriminating against race, ethnicity, religion, and class. Furthermore, the value of responsibility is very beneficial for the development of children's behavior. With the value of this character education, children will be willing to try to do or complete what they have to do. For example, such as doing assignments given by the teacher, maintaining the body's cleanliness and environment, and trying to solve any challenges they have started. Children must be accustomed to a routine in carrying out daily activities to have the responsibility to do it and complete it.

The value of patriotic is closely related to loving the country and being proud of the place, the area where he originates. The qualities of loving the region must be cultivated to have a strong identity, a strong character regarding their origins. Mainly as Balinese, children must be accustomed to loving Balinese culture, getting to know hero figures from Bali, stories with Balinese themes so that children become proud to be Balinese, Indonesians who can socialize and compete in the international world.

\section{Conclusion}

Learning English using the storytelling method uses puppets to tell the spirit of local Balinese heroism to make children enthusiastic about learning, watching every show that is displayed. Children love the stories that are told at the show. Children can understand simple new words in English, understand stories, and understand the social values contained in each story that is displayed even though they still have to be accompanied or guided by their parents. Learning through storytelling with YouTube media is also the right choice to stimulate children to be excited about learning because it is fascinating and able to stimulate the senses of sight and hearing through moving images and music. 


\section{Acknowledgments}

Finally, this research was able be completed by the authors well and quickly. In conducting this research, the author has been assisted by various parties both morally and materially. First of all, the authors would like to express profound gratitude for the presence of Ida Sang Hyang Widhi Wasa, The Almighty God; because of His grace, the writer was able to complete this research. Then the authors would like to thank the leaders of our institution, the Chairman of STAHN Mpu Kuturan Singaraja and the Rector of UNDIKNAS, who have provided moral support. Fellow lecturers who have helped morally and distributed questionnaires to teachers and parents of PAUD students. PPL students who have been willing to be the object of this research, as well as parents who have also given feedback in the form that can then be processed into data

\section{References}

Anand, A., Gupta, R. K., Raj, R., Sinha, R., Kumar, P., \& Raj, A. (2020). Information Technology in ELT (English Learning and Teaching). International Journal of English Learning \& Teaching Skills, 2(4), 1569-1583(15). https://doi.org/10.15864/ijelts.2402.

Anugerah, R., Gatot, Y., Yuliana, S., \& Riyanti, D. (2019). The Potential of English Learning Videos in Form of Vlog on Youtube for Elt Material Writers. ICoTE Proceedings, 2(2), 2685-1407. https://jurnal.untan.ac.id/index.php/icote/article/view/38232.

Asadullina, G. R., Korovkina, N. V., Sadretdinova, E. V., Badretdinovich, R. S., \& Hajrullina, N. G. (2020). Social Character: Issues of Methodology and Research Methods. Revista Amazonia Investiga, 9(26), 545-553. https://doi.org/10.34069/ai/2020.26.02.61.

Cahyono, B. Y. (2017). Potensi Video Cerita Animasi Untuk Pendidikan Karakter. Prosiding Seminar Nasional Mahasiswa Kerjasama Direktorat Jenderal Guru Dan Tenaga Kependidikan Kemendikbud 2016, 37-42. https://doi.org/https://core.ac.uk/download/pdf/267023912.pdf\#page=48.

Dahyat, T., Budimansyah, D., \& ... (2020). The Power of Wayang Golek (Puppet Show) in Character Education in School. PalArch's Journal of Archeology of Egyp/Eqyptology, 17(4), 1268-1280. https://www.archives.palarch.nl/index.php/jae/article/download/591/594.

Dewi, L. J. E., Permana, A. A. J., Purnamawan, I. K., \& Sudadana, I. K. (2019). Augmented Reality (AR)-Based Application to Introduce Nagasepaha North Bali Puppet Style Character. Journal of Physics: Conference Series, 1165(1). https://doi.org/10.1088/1742-6596/1165/1/012004.

Donohue, C. (2014). Technology and Digital Media in the Early Years: Tools for Teaching and Learning. Routledge.

Dwiaryanti, R. (2018). Growing Akhlaqul Karimah As Character Education To the Children Through "Omar and Hana" Cartoon Film Series. FIKROTUNA: Jurnal Pendidikan Dan Manajemen Islam, 8(2), 986-1000. https://doi.org/10.32806/jf.v8i2.3228.

Fajri, N., \& Hestaliana R, A. (2019). PKMS Pelatihan Bahasa Inggris Bagi Guru Tk Dalam Pembelajaran Bahasa Inggris Berbasis Pendidikan Karakter. Jurnal Ilmiah Pendidikan Anak (JIPA), 4(6), 36-57. http://jurnal.stkipannur.ac.id/index.php/jipa/article/view/112.

Flick, U. (2018). Triangulation in Data Collection. In The SAGE handbook of qualitative data collection (pp. 527-544). https://doi.org/10.4135/9781526416070.n34.

Fraenkel, J. R., \& Wallen, N. E. (2008). Introduction to Qualitative Research: How to Design and Evaluate Research in Education (7th ed.). McGraw-Hill.

Gerring, J. (2007). Case Study Research: Principles and Practices. Cambridge University 
Press.

Golann, J. W. (2017). Conformers, Adaptors, Imitators, and Rejecters: How No-excuses Teachers' Cultural Toolkits Shape Their Responses to Control. Sociology of Education, 91(1), 28-45. https://doi.org/10.1177/0038040717743721.

Hakim, L. N. (2019). The Implementation of Youtube in Teaching Vocabulary for Young Learners. Journal of Advanced English Studies, 2(1), 12-18. https://doi.org/10.47354/jaes.v2i1.50.

Halimah, L., Arifin, R. R. M., Yuliariatiningsih, M. S., Abdillah, F., \& Sutini, A. (2020). Storytelling through "Wayang Golek" Puppet Show: Practical ways in incorporating character education in early childhood. Cogent Education, 7(1). https://doi.org/10.1080/2331186X.2020.1794495.

Heigham, J., \& Croker, R. (2009). Qualitative Research in Applied Linguistics: A Practical Introduction. Palgrave Macmillan. https://doi.org/10.1057/9780230239517.

Hermayawati. (2019). Self-Assessment Pada Pembelajaran Writing Menggunakan Integrated Cutural Language Learning Approach, Blended Learning Dan High Order Thinking Skills Untuk Preservasi Wayang Orang.

Hung, H.-T., Yang, J. C., Hwang, G. J., Chu, H.-C., \& Wang, C.-C. (2018). A scoping review of research on digital game-based language learning. Computers \& Education, 128(1), 89-104. https://doi.org/10.1016/j.compedu.2018.07.001.

Leong, A. C. H., Abidin, M. J. Z., \& Saibon, J. S. (2019). Learners' Perceptions of the Impact of Using Digital Storytelling On Vocabulary Learning. The Journal of Teaching English with Technology, 19(4), 3-26. https://www.ceeol.com/search/articledetail?id=803686.

Mabruri, H., Ahmadi, F., \& Suminar, T. (2019). The Development of Science Mobile Learning Media to Improve Primary Students Learning Achievements Article Info. Journal of Primary Education, 8(1), 108-116. https://journal.unnes.ac.id/sju/index.php/jpe/article/view/25391.

Maulina, K. (2017). The Implementation of Riddle Game Media to Increase Students' Ability in Speaking for The Eleventh Grade Students of Mas. PP. Raudhatul Hasanah, Paya Bundung, Medan. State Islamic University North Sumatera Medan.

Miles, M. B., \& Huberman, A. M. (1994). Qualitative Data Analysis: An Expanded Sourcebook (2nd ed.). SAGE Publications Inc.

Moleong, L. J. (2013). Metodologi Penelitian Kualitatif. PT. Remaja Rosdakarya Offset.

Morat, B. N., Shaari, A., Abidin, M. J. Z., \& Abdullah, A. (2017). Youtube within ESL classroom: Exploring an instructor's and her learners' experiences concerning the authenticity of language and technology use. Malaysian Journal of Learning and Instruction, 2017(Special Issue), 173-196. https://doi.org/10.32890/mjli.2017.7802.

Nasution, A. K. R. (2019). YouTube as a Media in English Language Teaching (ELT) Context: Teaching Procedure Text. Utamax: Journal of Ultimate Research and Trends in Education, 1(1), 29-33. https://doi.org/10.31849/utamax.v1i1.2788.

Noble, H., \& Heale, R. (2019). Triangulation in research, with examples. Evidence-Based Nursing, 22(3), 67-68. https://doi.org/10.1136/ebnurs-2019-103145.

Nurapriani, R., Yanuarsari, R., Ruswandi, A., Muchtar, H., \& Hakim, L. (2019). Indonesian Vocabulary Learning for Early Childhood Using Paper Puppet Media. ICSTI 2018, April. https://doi.org/10.4108/eai.19-10-2018.2281317.

Pandya, B. (2016). Technology Integrated English Language Teaching : A Shift towards New Methodologies in ELT. 36 36. http://eltvoices.in/Volume6/Issue_3/EVI_63_4.pdf.

Parette, H. P., \& Blum, C. (2013). Instructional Technology in Early Childhood: Teaching in the Digital Age. Paul H. Brookes Publishing Company. 
Purandina, I. P. Y. (2020). The Use of English Classroom Greeting and Character Building in TK Pelita Sari Desa Mambang Tabanan. Jurnal Pendidikan Bahasa Inggris Indonesia, 8(2), 12-19. https://doi.org/10.23887/jpbi.v8i2.3495.

Purandina, I. P. Y., \& Winaya, I. M. A. (2020). Pendidikan Karakter di Lingkungan Keluarga Selama Pembelajaran Jarak Jauh pada Masa Pandemi COVID-19. Cetta: Jurnal Ilmu Pendidikan, 3(2), 270-290. https://doi.org/10.37329/cetta.v3i2.454.

Rakiyah, S. (2014). The Impact of Animation Media On the Character of Children in TK Starlight Education. Komunikologi: Jurnal Pengembangan Ilmu Komunikasi Dan Sosial, 1(1), 29-35. https://doi.org/10.30829/komunikologi.v3i1.5049.

Renz, S. M., Carrington, J. M., \& Badger, T. A. (2019). Two Strategies for Qualitative Content Analysis: An Intramethod Approach to Triangulation. Qualitative Health Research, 28(5), 824-831. https://doi.org/10.1177/1049732317753586.

Roulston, K. (2018). Triangulation in qualitative research. In QualPage.

Rustan, E. (2020). Stimulation of child's sexual imitation behavior through Neurolinguistic programming. Jurnal Konseling Dan Pendidikan, 8(2), 61. https://doi.org/10.29210/136300.

Saiful, J. A. (2019). EFL Teachers' Cognition in the Use of Youtube Vlog in English Language Teaching. Journal of Foreign Language Education and Technology, 4(2), 72-91. https://www.ceeol.com/search/article-detail?id=781396.

Sugiyono. (2019). Metode Penelitian Kualitatif. Alfabeta.

Suhana, M. (2018). Influence of Gadget Usage on Children's Social-Emotional Development. 169(Icece 2017), 224-227. https://doi.org/10.2991/icece-17.2018.58.

Sulistiyanto, Ali, Y., Fitriati, R., \& Hamidah. (2019). Implementation of State Defense Characters in Early Childhood Education. 45th International Scientific Conference on Economic and Social Development - XIX International Social Congress (ISC 2019), 2019(1). https://www.bib.irb.hr/1035265/download/1035265.Book_of_Proceedings_ esdMoscow2019_Online.pdf\#page=104.

Swart, J., Peters, C., \& Broersma, M. (2019). Sharing and Discussing News in Private Social Media Groups: The social function of news and current affairs in location-based, work-oriented and leisure-focused communities. Digital Journalism, 7(2), 187-205. https://doi.org/10.1080/21670811.2018.1465351.

Tetep, \& Suparman, A. (2019). Students' digital media literacy: Effects on social character. International Journal of Recent Technology and Engineering, 8(2 Special Issue 9), 394-399. https://doi.org/10.35940/ijrte.B1091.0982S919.

Umaya, N. M., Sarwiji, Budiyono, \& Andayani. (2016). Heroism Concept in Fairy-Tales Teaching Materials Influencing Students Dealing with Student Brawl. International Journal of Language and Literature, 4(1), 295-298. https://doi.org/10.15640/ijll.v4n1a35.

Wijayanti, K. D., \& Sulaksono, D. (2019). Character Building for Early Childhood Learners Through the Shadow Puppet-Based Javanese Language Manners. Third International Conference of Arts, Language and Culture (ICALC 2018), 353-360. https://doi.org/10.2991/icalc-18.2019.50.

Winarto, W., Syahid, A., \& Saguni, F. (2020). Effectiveness the Use of Audio Visual Media in Teaching Islamic Religious Education. International Journal of Contemporary Islamic Education, 2(1), 81-107. https://doi.org/10.24239/ijcied.vol2.iss1.14.

Yusuf, R. (2020). Teaching EFL Students Using Selected Media: Offline Video Taken From YouTube. Utamax: Journal of Ultimate Research and Trends in Education, 2(1), 2933. https://doi.org/10.31849/UTAMAX.V2I1.2909. 